This item was submitted to Loughborough's Research Repository by the author.

Items in Figshare are protected by copyright, with all rights reserved, unless otherwise indicated.

\title{
Effects of solute $\mathrm{Nb}$ atoms and $\mathrm{Nb}$ precipitates on isothermal transformation kinetics from austenite to ferrite
}

PLEASE CITE THE PUBLISHED VERSION

http://dx.doi.org/10.1007/s11661-016-3548-x

\section{PUBLISHER}

Springer (@ The Minerals, Metals \& Materials Society and ASM International 2016)

\section{VERSION}

AM (Accepted Manuscript)

\section{PUBLISHER STATEMENT}

This work is made available according to the conditions of the Creative Commons Attribution-NonCommercialNoDerivatives 4.0 International (CC BY-NC-ND 4.0) licence. Full details of this licence are available at: https://creativecommons.org/licenses/by-nc-nd/4.0/

\section{LICENCE}

CC BY-NC-ND 4.0

\section{REPOSITORY RECORD}

Wang, Li, Sally V. Parker, Andrew J. Rose, G.D. West, and Rachel Thomson. 2016. "Effects of Solute Nb Atoms and Nb Precipitates on Isothermal Transformation Kinetics from Austenite to Ferrite". figshare. https://hdl.handle.net/2134/22108. 


\title{
Effects of solute $\mathrm{Nb}$ atoms and $\mathrm{Nb}$ precipitates on isothermal transformation kinetics from austenite to ferrite
}

\author{
Li Wang $^{1^{*}}$, Sally Parker ${ }^{2}$, Andrew Rose ${ }^{2}$, Geoff West $^{1}$, Rachel Thomson $^{1}$ \\ 1. Department of Materials, Loughborough University, Loughborough, LE11 3TU, UK \\ 2. Materials Design Department, Tata Steel R\&D, Swinden Technology Centre, Rotherham, S60 3AR, UK
}

\begin{abstract}
:
$\mathrm{Nb}$ is a very important micro-alloying element in low-carbon steels, for grain size refinement and precipitation strengthening, and even a low content of $\mathrm{Nb}$ can result in a significant effect on phase transformation kinetics from austenite to ferrite. Solute $\mathrm{Nb}$ atoms and $\mathrm{Nb}$ precipitates may have different effects on transformation behaviors, and these effects have not yet been fully characterized. This paper examines in detail the effects of solute $\mathrm{Nb}$ atoms and $\mathrm{Nb}$ precipitates on isothermal transformation kinetics from austenite to ferrite. The mechanisms of the effects have been analyzed using various microscopy techniques. Many solute $\mathrm{Nb}$ atoms were found to be segregated at the austenite/ferrite interface and apply a solute drag effect. It has been found that solute $\mathrm{Nb}$ atoms have a retardation effect on ferrite nucleation rate and ferrite grain growth rate. The particle pinning effect caused by $\mathrm{Nb}$ precipitates is much weaker than the solute drag effect.
\end{abstract}

Key words: Nb; transformation kinetics; solute drag effect; low carbon steels

\section{Introduction}

During steel manufacturing, many alloying elements are added for various purposes. $\mathrm{Nb}$ is one of the most important micro-alloying elements in low-carbon steels. The large misfit between $\mathrm{Nb}$ atoms and the austenite matrix makes the solubility of $\mathrm{Nb}$ in

\footnotetext{
* Li Wang Now moves to Jaguar Land Rover UK, Mobile: +44 (0) 7859255713. Email address: liwangmaterials@outlook.com.
} 
austenite low, and thus the $\mathrm{Nb}$ content in low-carbon steels is normally quite low, i.e., less than $0.05 \mathrm{wt}$ pct. $\mathrm{Nb}$ has a strong tendency to form a carbo-nitride, and thus there are two typical forms of $\mathrm{Nb}$ present in steels during steel manufacturing, which are solute $\mathrm{Nb}$ atoms and $\mathrm{Nb}$ carbo-nitride precipitates [1-5]. Nb addition in steels is beneficial for mechanical properties by grain size refinement and precipitation strengthening. $\mathrm{Nb}$ can also be used to control the transformation kinetics, and thus hardenability is improved by the presence of solute Nb [1-7].

The effects of $\mathrm{Nb}$ on steel manufacturing have been studied widely by many researchers. Many of them state that $\mathrm{Nb}$ has a retardation effect on phase transformation kinetics in steels [6-18] and even a small amount of $\mathrm{Nb}$ (i.e., less than 0.05 wt pct) can result in significant effects on transformation behavior and mechanical properties. The presence of $\mathrm{Nb}$ in steels also affects the final microstructure after phase transformations [18]. However, the effects of $\mathrm{Nb}$ on isothermal transformation kinetics from austenite to ferrite have not yet been fully characterized and quantified. In particularly, the two forms of $\mathrm{Nb}$ in steels, solute $\mathrm{Nb}$ atoms and $\mathrm{Nb}$ precipitates, can affect phase transformation kinetics via different mechanisms, which are the solute drag effect and particle pinning effect. Since there is still controversy about the exact nature of the retardation mechanism $[7,16]$ advanced microscopy techniques can be utilized for samples with different heat treatments to characterize the solute drag effect and the particle pinning effect. The solute drag effect has been demonstrated by many previous researchers [19-23]. Its basic requirement is the segregation of solute atoms to the transformation interface, and thus the grain boundary mobility is inhibited. Felfer et al.[23] have utilized atom probe study to find that the interfacial excess $\mathrm{Nb}$ atoms at prior austenite grain boundaries are more than those at ferrite-ferrite grain boundaries. Fazeli and Militzer [24] have successfully studied the solute drag effect in Fe-C-Mn ternary system, but the solute drag effect caused by $\mathrm{Nb}$ has not yet been fully understood. Nb carbonitride particles are quite small (typically tens of nanometers) after typical heat treatments in steels. The combination of the small particle size and the low content of $\mathrm{Nb}$ make it difficult to observe $\mathrm{Nb}$ precipitates.

Austenite grain growth, which has a significant effect on the subsequent transformation kinetics, is also affected by the presence of $\mathrm{Nb}$. In order to accurately 
study the effects of $\mathrm{Nb}$ on transformation behavior, it is important to isolate the effects of austenite grain size, solute $\mathrm{Nb}$ atoms, and $\mathrm{Nb}$ precipitates. Nucleation and ferrite grain growth are the two stages in a typical reconstructive transformation from austenite to ferrite. It is essential to study nucleation rate and grain growth rate separately for fully understanding the effects of $\mathrm{Nb}$ on transformation kinetics.

\section{Experimental procedure}

Five laboratory-cast low-carbon steels with the same base chemistry but different $\mathrm{Nb}$ contents were provided by Tata Steel, and their chemical compositions are listed in Table I. Steels 1 to 3 are from the same batch, but steels 4 and 5 are from another batch with different initial processing conditions.

Table 1 Chemical compositions (wt. \%) and thermodynamic calculation results

\begin{tabular}{ccccccccccc}
\hline Steel & $\mathrm{C}$ & $\mathrm{Nb}$ & $\mathrm{N}$ & $\mathrm{Si}$ & $\mathrm{Mn}$ & $\mathrm{Al}$ & $\mathrm{Ti}$ & $\mathrm{Fe}$ & $\begin{array}{c}\mathrm{Nb}(\mathrm{C}, \mathrm{N}) \\
\text { dissolution }\end{array}$ & $\mathrm{Ae}_{3}$ \\
\hline 1 & 0.110 & $<0.001$ & 0.006 & 0.23 & 0.99 & 0.034 & 0.001 & $\mathrm{Bal}$ & $\mathrm{N} / \mathrm{A}$ & $1117 \mathrm{~K}$ \\
2 & 0.105 & 0.009 & 0.006 & 0.23 & 1.00 & 0.030 & 0.001 & $\mathrm{Bal}$ & $1293 \mathrm{~K}$ & $1119 \mathrm{~K}$ \\
3 & 0.105 & 0.028 & 0.006 & 0.23 & 0.99 & 0.031 & 0.001 & $\mathrm{Bal}$ & $1414 \mathrm{~K}$ & $1119 \mathrm{~K}$ \\
4 & 0.088 & 0.045 & 0.005 & 0.23 & 1.01 & 0.032 & $<0.001$ & $\mathrm{Bal}$ & $1447 \mathrm{~K}$ & $1132 \mathrm{~K}$ \\
5 & 0.096 & 0.067 & 0.005 & 0.23 & 1.01 & 0.029 & $<0.001$ & $\mathrm{Bal}$ & $1493 \mathrm{~K}$ & $1130 \mathrm{~K}$ \\
\hline
\end{tabular}

Samples were cut into cylinders with a length of $10 \mathrm{~mm}$ and a diameter of $5 \mathrm{~mm}$ for dilatometer operation. A dilatometer (DIL 805A/D) was utilized for heat treatments and recording transformation kinetics. ThermoCalc in conjunction with the TCFE v6 database was utilized for thermodynamic calculations of the precipitate dissolution and phase transformation temperatures (Table I) which were used to determine appropriate heat treatment temperatures. The heat treatment temperature profiles are shown in Figure 1. Samples were fast heated to $1523 \mathrm{~K}\left(1250^{\circ} \mathrm{C}\right)$ to transform to austenite and fully dissolve pre-existing $\mathrm{Nb}$ precipitates, and holding times were varied for different steels in order to make all the samples with the same average prior austenite grain size. They were then fast cooled to $1173 \mathrm{~K}\left(900^{\circ} \mathrm{C}\right)$ and held for a certain time (i.e., 5, 20, or 60 minutes) to allow $\mathrm{Nb}$ carbo-nitride precipitation to occur. After that, they were fast cooled to isothermal transformation temperatures between $1023 \mathrm{~K}\left(750^{\circ} \mathrm{C}\right)$ and $923 \mathrm{~K}\left(650^{\circ} \mathrm{C}\right)$, and held for 10,30 seconds, 1, 2, 3, or 15 minutes. Finally, the samples were quenched to room temperature. Some 
samples were fast cooled directly from $1523 \mathrm{~K}\left(1250^{\circ} \mathrm{C}\right)$ to the isothermal transformation temperatures without the precipitation holding at $1173 \mathrm{~K}\left(900^{\circ} \mathrm{C}\right)$, in order to retain $\mathrm{Nb}$ atoms in solid solution at the beginning of the isothermal transformation. A sample was quenched directly from $1523 \mathrm{~K}$ to room temperature in order to analyze whether $\mathrm{Nb}$ carbo-nitride particles can be formed during the fast cooling. Additional samples were austenitized at $1373 \mathrm{~K}\left(1100^{\circ} \mathrm{C}\right)$ for a certain time, in order to avoid the complete dissolution of pre-existing $\mathrm{Nb}$ precipitates, before undergoing isothermal transformations as before.

After the heat treatments, the samples were prepared using standard metallurgical preparation methods including cutting, mounting, grinding, polishing, and sometimes chemical etching with 2 pct Nital. A Reichert-Jung MEF3 reflective optical microscope, a Zeiss 1530VP field emission gun scanning electron microscope (FEGSEM), an FEl Nova 600 NanoLab dual beam system which consists of FEGSEM and a gallium source focused ion beam (FIB), a JEOL 2000FX transmission electron microscope (TEM) equipped with an Energy-Dispersive $X$-ray (EDX) detector, and an FEI Tecnai F20 field emission gun transmission electron microscope (FEGTEM) fitted with high angle annular dark field (HAADF) detector and X-Max $80 \mathrm{~mm}$ SDD detector were utilized to investigate the resulting microstructures.

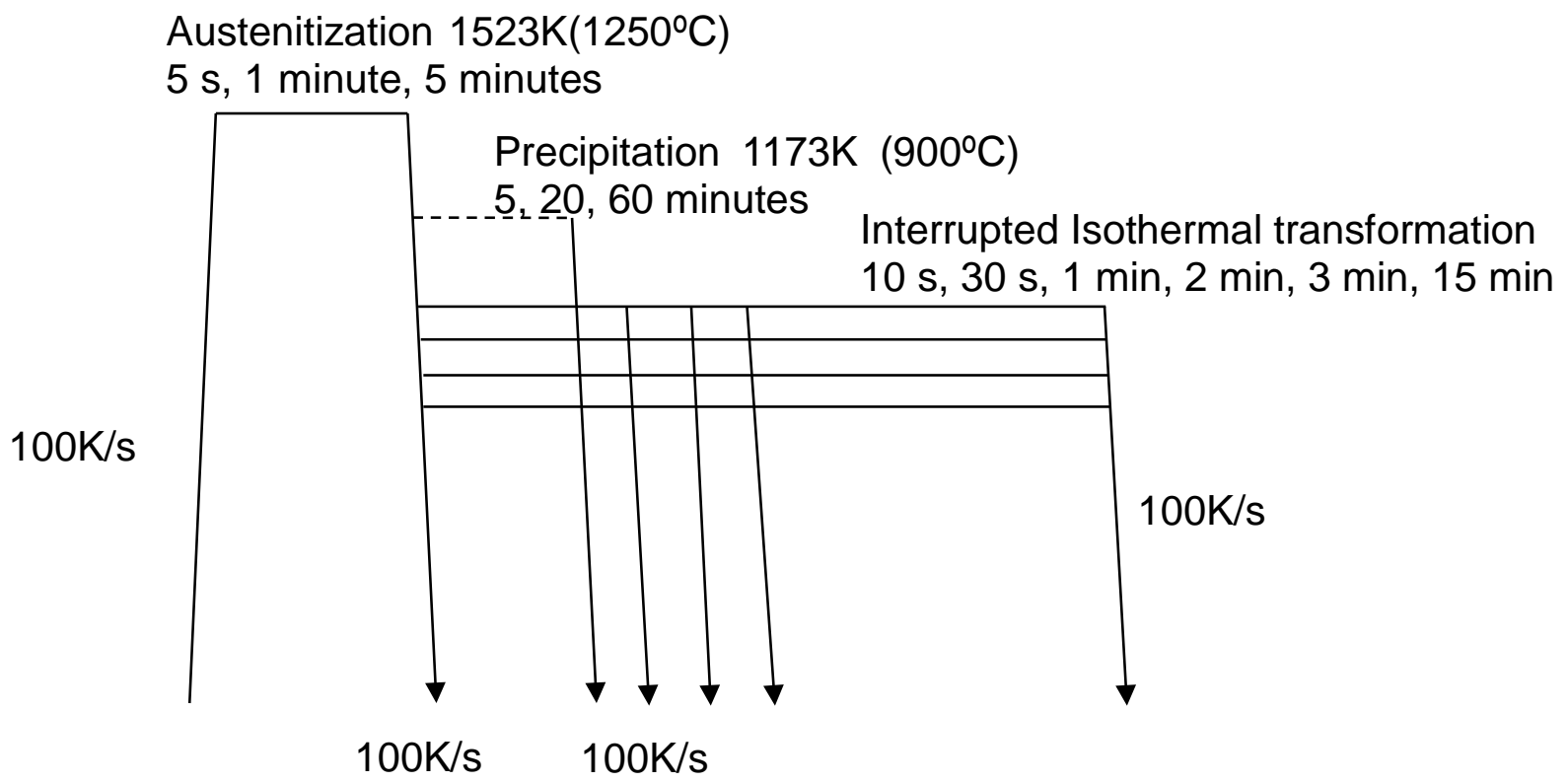

Fig. 1: Temperature profile for interrupted isothermal transformations. 


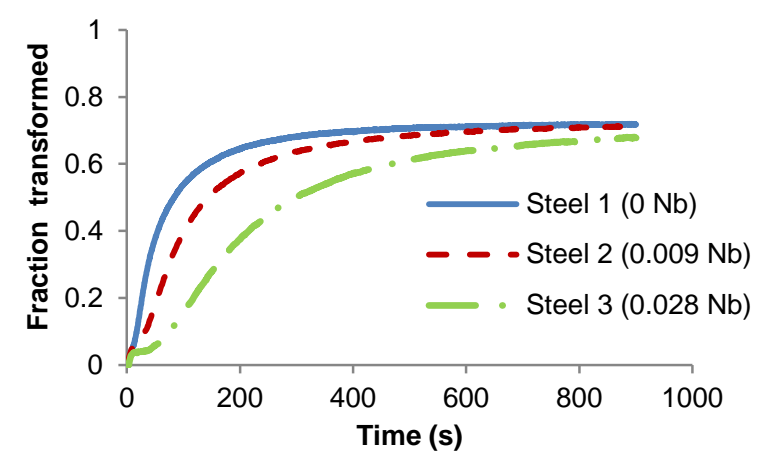

(a)

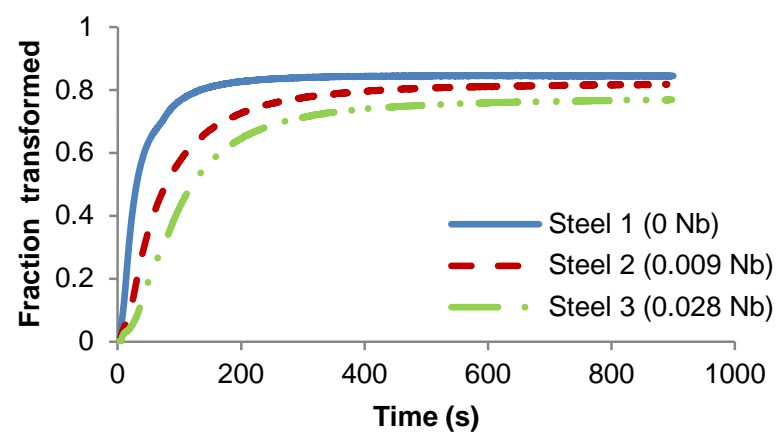

(c)

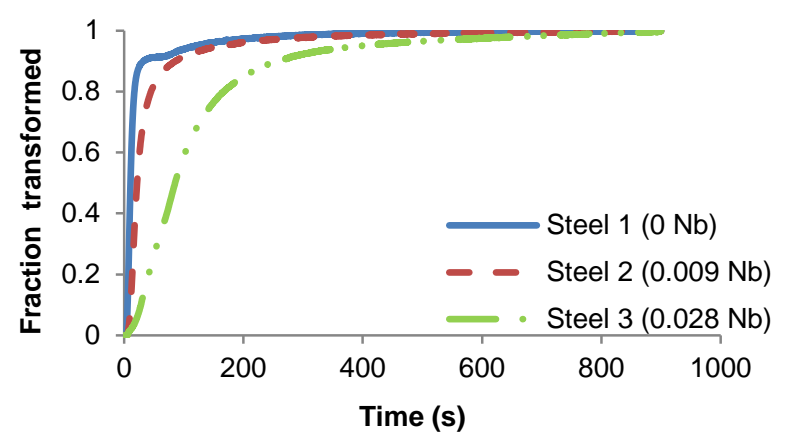

(e)

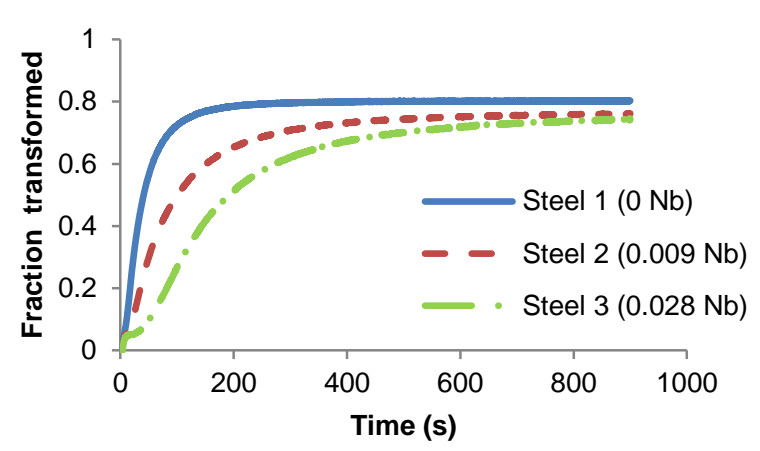

(b)

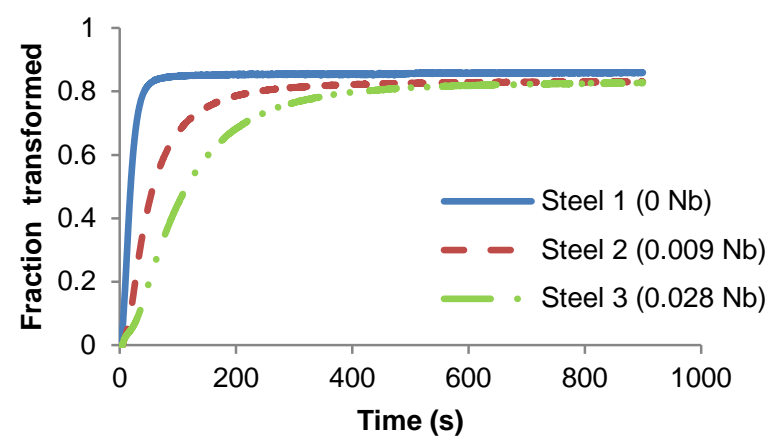

(d)

Fig. 2: Isothermal transformation kinetics for steels 1-3 with the same prior austenite grain size at (a) $1023 \mathrm{~K}\left(750^{\circ} \mathrm{C}\right)$, (b) $998 \mathrm{~K}\left(725^{\circ} \mathrm{C}\right),(\mathrm{c}) 973 \mathrm{~K}\left(700^{\circ} \mathrm{C}\right),(\mathrm{d}) 948 \mathrm{~K}\left(675^{\circ} \mathrm{C}\right)$, and (e) 923K $\left(650^{\circ} \mathrm{C}\right)$.

\section{Effects of solute $\mathrm{Nb}$ atoms on isothermal transformation}

In order to study the effect of solute $\mathrm{Nb}$ atoms on transformation kinetics, steels 1 to 3 with similar chemical compositions except for the $\mathrm{Nb}$ content were heated to 1523 $\mathrm{K}\left(1250^{\circ} \mathrm{C}\right)$ to ensure that all pre-existing $\mathrm{Nb}(\mathrm{C}, \mathrm{N})$ precipitates were fully dissolved. From thermodynamic calculation, the solubility of $\mathrm{Nb}$ at $1523 \mathrm{~K}$ for a steel with $0.1 \mathrm{wt}$ pct $C$ is 0.09 wt pct. The austenitization times were carefully chosen to obtain an average prior austenite grain size of $\sim 80 \mathrm{~lm}$ in each sample. Therefore, the 
subsequent isothermal transformation should only be affected by any difference in solute $\mathrm{Nb}$ atoms.

The transformation kinetics curves of steels 1 to 3 during 15-minute isothermal transformations at $1023 \mathrm{~K}\left(750^{\circ} \mathrm{C}\right), 998 \mathrm{~K}\left(725^{\circ} \mathrm{C}\right), 973 \mathrm{~K}\left(700^{\circ} \mathrm{C}\right), 948 \mathrm{~K}\left(675^{\circ} \mathrm{C}\right)$, and $923 \mathrm{~K}\left(650^{\circ} \mathrm{C}\right)$ are plotted in Figures 2(a) through (e), respectively. It can be clearly observed that steel 3 with $0.028 \mathrm{wt}$ pct $\mathrm{Nb}$ always has the slowest transformation kinetics, and steel 1 with no $\mathrm{Nb}$ always has the fastest transformation kinetics in the steels. In this temperature range, the isothermal transformations are mainly occurring by the reconstructive mechanism to transform to polygonal ferrite. However, at $923 \mathrm{~K}\left(650^{\circ} \mathrm{C}\right)$, from Figure 2(e), it can be found that steel 1 has a 'stasis' after 90 pct transformation, and the transformation restarts after tens of seconds. This phenomenon has also been found by Furuhara et al.[25] in upper bainite transformation at $853 \mathrm{~K}$ and $873 \mathrm{~K}\left(580^{\circ} \mathrm{C}\right.$ and $\left.600^{\circ} \mathrm{C}\right)$. From the optical micrographs shown in Figures 3(e) and (f), steels 1 and 3 have different microstructures after the 15-minute isothermal transformations at the same temperature of $923 \mathrm{~K}\left(650^{\circ} \mathrm{C}\right)$. Steel 1 has a combination of displacive and diffusional transformation products, but steel 3 was mainly ferrite, pearlite, and martensite. Therefore, their transformation kinetics can not only be directly compared at this temperature, but it also indicates that the presence of $\mathrm{Nb}$ has an effect on the competition between diffusional and displacive transformation mechanisms.

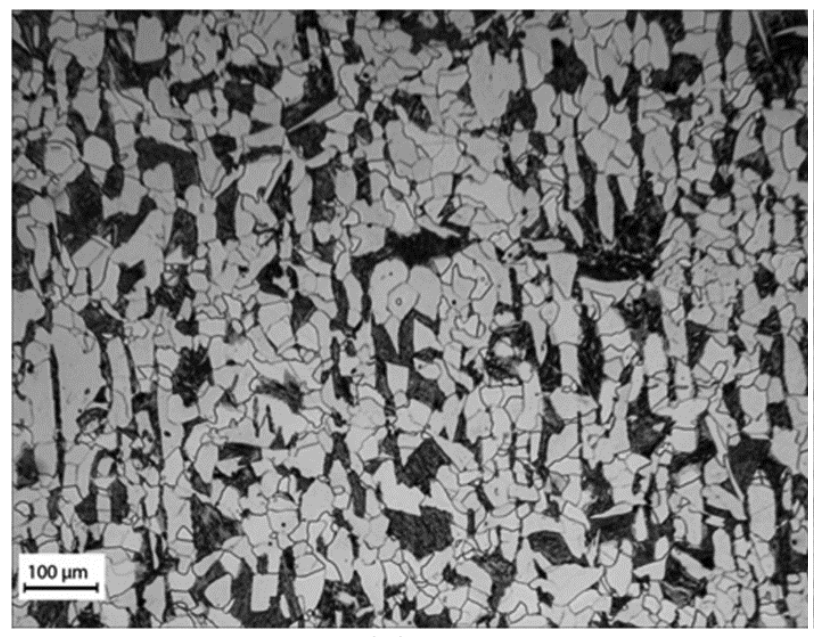

(a)

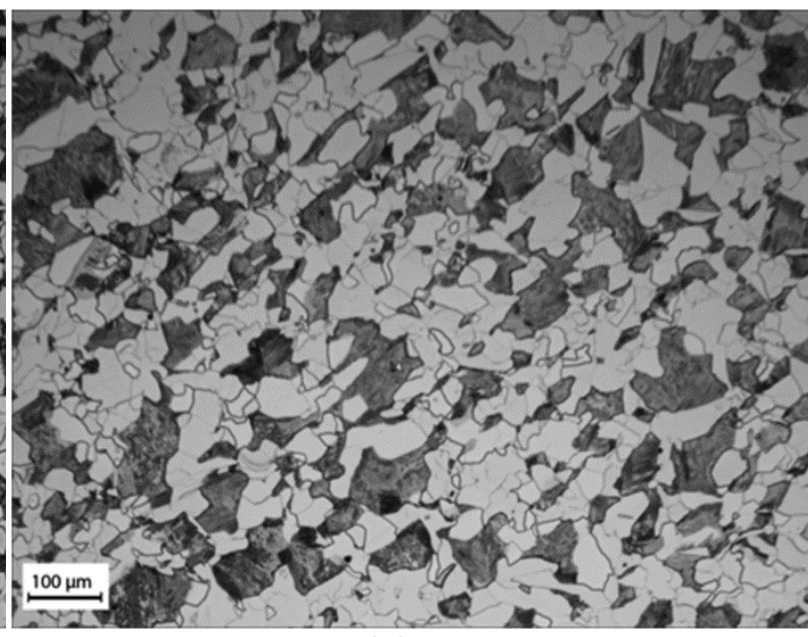

(b) 


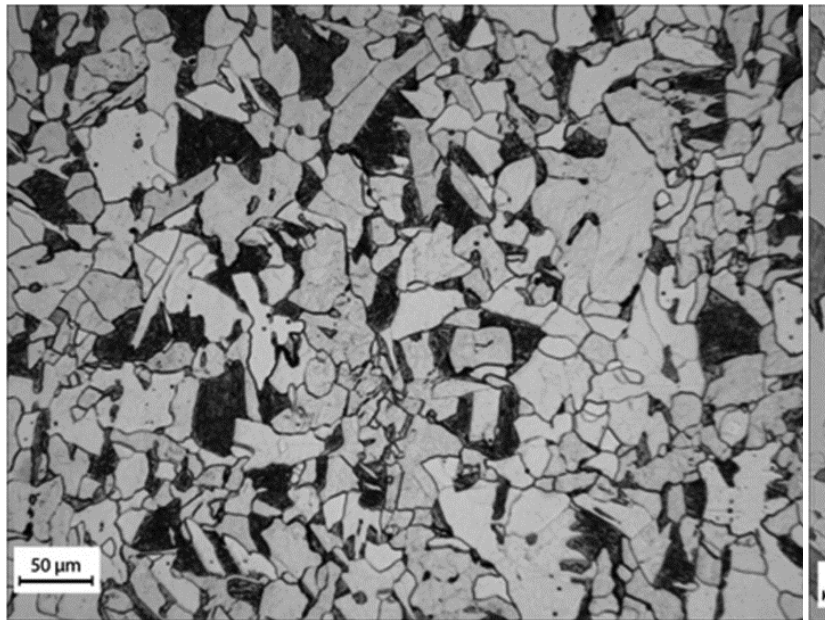

(c)

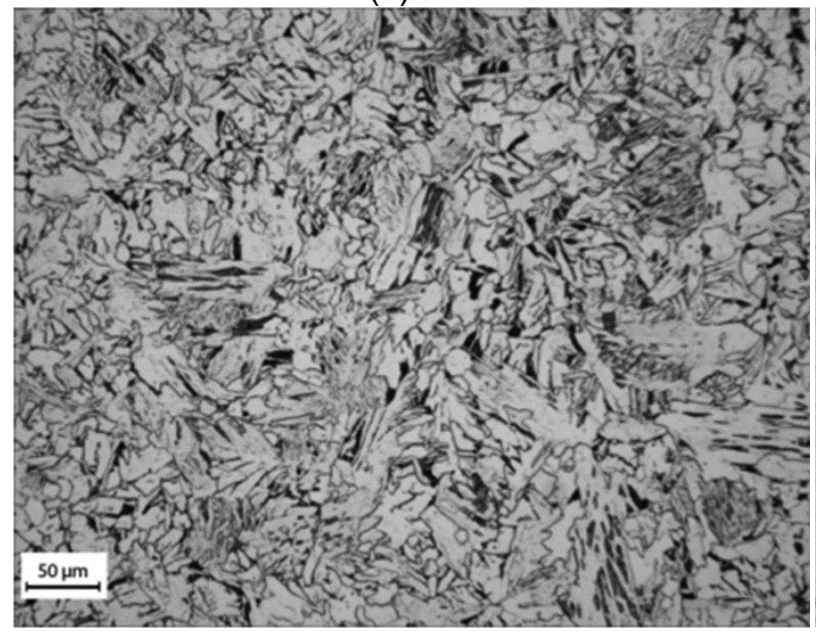

(e)

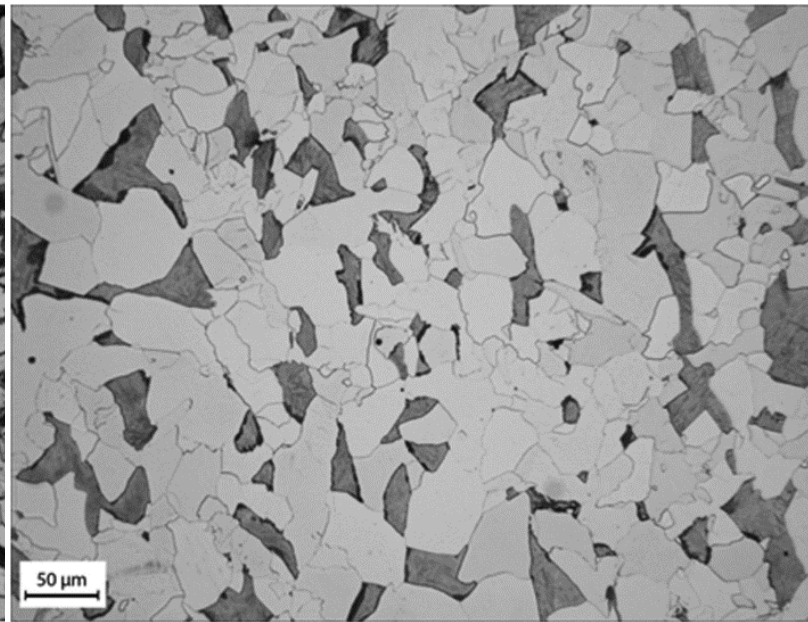

(d)

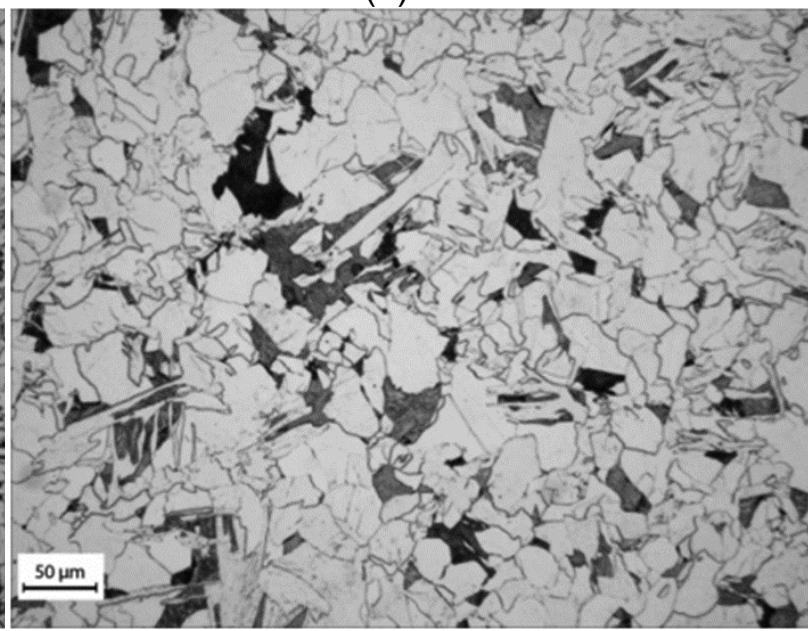

(f)

Fig.3: Optical micrographs of steels 1 and 3 after 15 minutes isothermal transformations: (a) steel 1 at $1023 \mathrm{~K}\left(750^{\circ} \mathrm{C}\right)$, (b) steel 3 at $1023 \mathrm{~K}\left(750^{\circ} \mathrm{C}\right)$, (c) steel 1 at $973 \mathrm{~K}\left(700^{\circ} \mathrm{C}\right)$, (d) steel 3 at $973 \mathrm{~K}\left(700^{\circ} \mathrm{C}\right),(\mathrm{e})$ steel 1 at $923 \mathrm{~K}\left(650^{\circ} \mathrm{C}\right)$, and (f) steel 3 at $923 \mathrm{~K}\left(650^{\circ} \mathrm{C}\right)$.

All of these isothermal transformation results indicate that a steel with a higher $\mathrm{Nb}$ content always has slower isothermal transformation kinetics. The steels were all austenitized at $1523 \mathrm{~K}\left(1250^{\circ} \mathrm{C}\right)$ which is much higher than the $\mathrm{Nb}(\mathrm{C}, \mathrm{N})$ dissolution temperatures. Therefore, the $\mathrm{Nb}$ should be in solid solution form at the beginning of the isothermal transformation, and this has been investigated by the TEM carbon extraction replica study on samples quenched directly from $1523 \mathrm{~K}\left(1250^{\circ} \mathrm{C}\right)$, in which no $\mathrm{Nb}(\mathrm{C}, \mathrm{N})$ particles were observed. However, from a TEM carbon extraction replica study on the isothermally transformed samples from steel 3 after quenching directly from $1523 \mathrm{~K}\left(1250^{\circ} \mathrm{C}\right)$, there were a lot of $\mathrm{Nb}(\mathrm{C}, \mathrm{N})$ particles segregated near grain boundaries, as indicated by the arrows in Figure 4 . These $\mathrm{Nb}(\mathrm{C}, \mathrm{N})$ particles are quite small, with a typical diameter of $\sim 10 \mathrm{~nm}$, which is much smaller than that of typical pre-existing $\mathrm{Nb}(\mathrm{C}, \mathrm{N})$ particles. It is reasonable to suggest that during the 
isothermal transformations, solute $\mathrm{Nb}$ atoms were segregated at grain boundaries where they acted to delay the transformation kinetics, and then precipitated as $\mathrm{Nb}(\mathrm{C}, \mathrm{N})$ particles which were left near the grain boundary during the subsequent isothermal transformation.

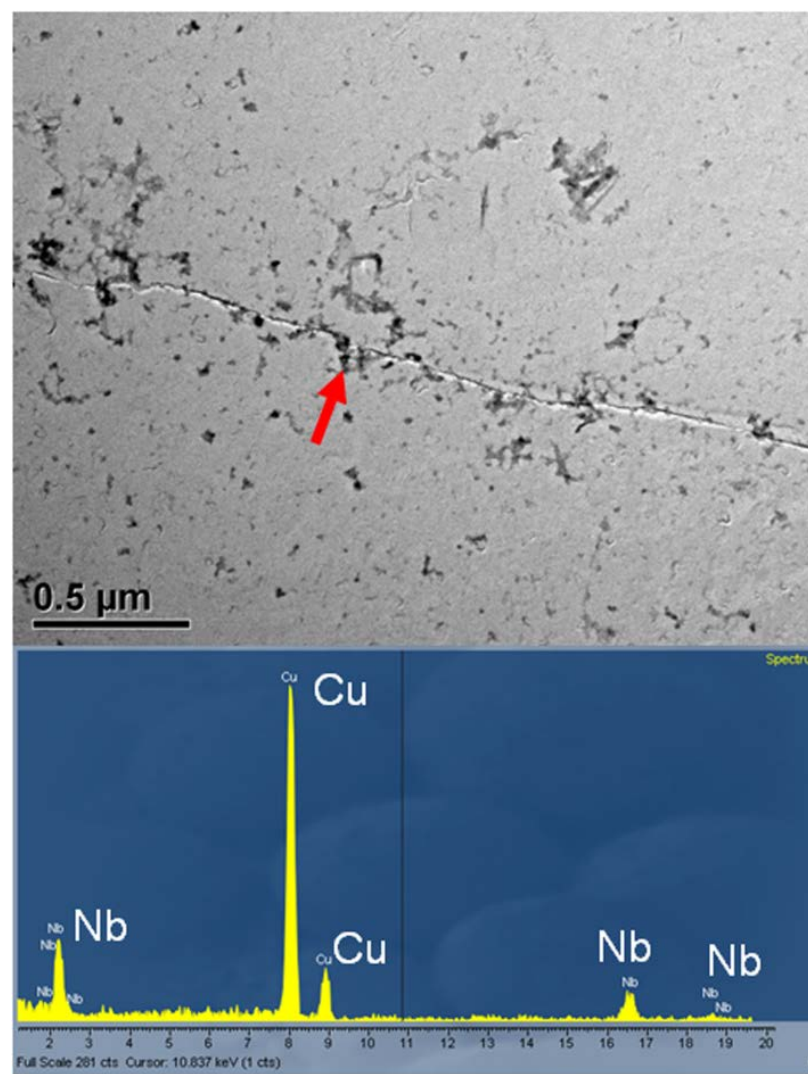

(a)

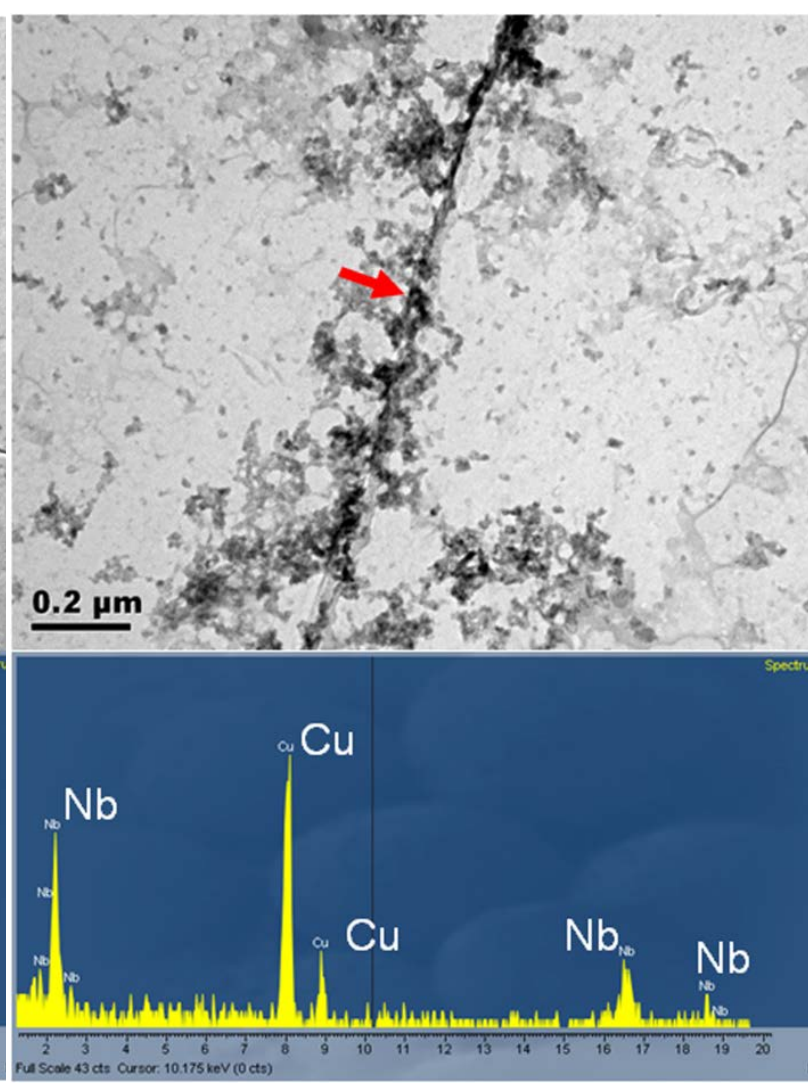

(b)

Fig. 4: TEM images and the related EDX spectrum of carbon extraction replica samples from steel 3 after isothermal transformation at (a) $923 \mathrm{~K}\left(650^{\circ} \mathrm{C}\right)$ and (b) $973 \mathrm{~K}\left(700^{\circ} \mathrm{C}\right)$.

\section{Interrupted isothermal transformations}

A typical isothermal transformation from austenite to ferrite has a parabolic kinetic curve. The ferrite nucleation rate and ferrite grain growth rate are the two key factors for the transformation kinetics. In order to accurately study the effect of solute $\mathrm{Nb}$ atoms on each rate, the isothermal transformations were interrupted after a certain time and then the samples were quenched to room temperature. For each interrupted sample, the average ferrite grain size was measured using linear intercept method and number of ferrite grains was counted. Ferrite grain sizes during holding at $1023 \mathrm{~K}\left(750^{\circ} \mathrm{C}\right)$ for the three steels are plotted in Figure 5(a), and an error bar shows the standard deviation of grain size. The curves of average number of ferrite grains per unit area as a function of holding time for the steels are plotted in 
Figure 5(b), and an error bar shows the standard deviation of the number of grains per unit area for all the micrographs in a steel.

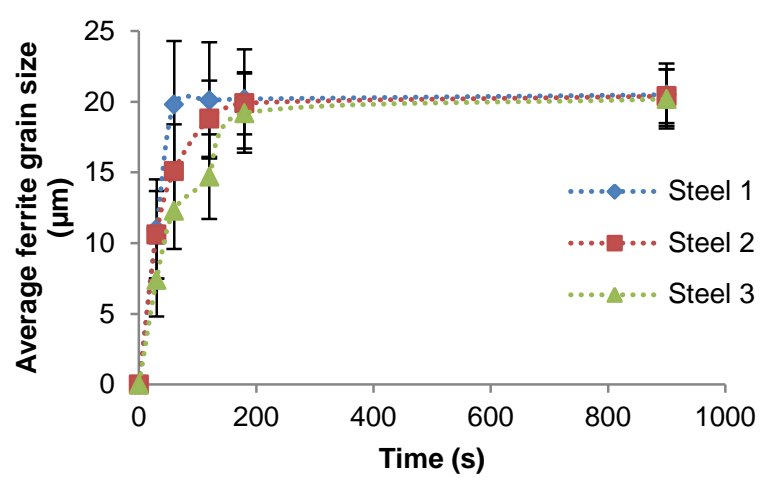

(a)

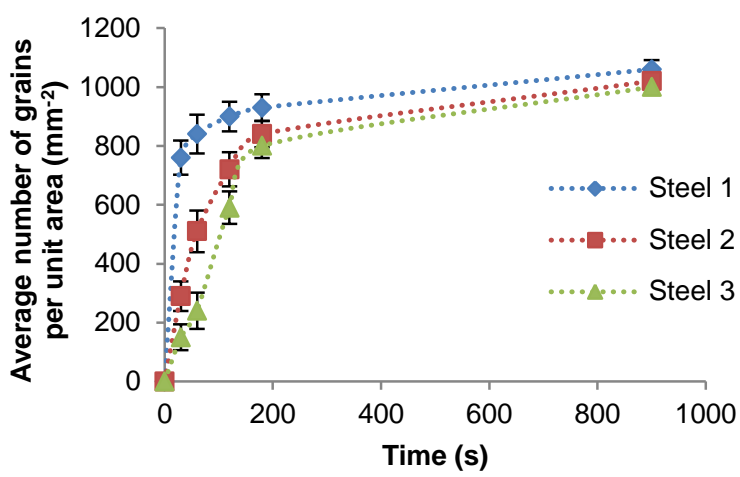

(b)

Fig. 5: (a) Average ferrite grain size (an error bar shows the standard deviation of grain size, and (b) average number of ferrite grains per unit area (an error bar shows the standard deviation of the number of grains per unit area for all the micrographs in a steel), during isothermal transformations at $1023 \mathrm{~K}\left(750^{\circ} \mathrm{C}\right)$ for steels $1-3$.

For the $\mathrm{Nb}$-free steel 1 , it was found that the number of ferrite grains increased quickly in the first tens of seconds, and the ferrite grain size also grew quickly simultaneously. After that, the ferrite grain size became stable, but there was still a slow increase in the number of ferrite grains. In this work, the nucleation rate is calculated by $d N / d t$, where $N$ is the number of ferrite grains and $t$ is the time. The ferrite grain growth rate is calculated by $\mathrm{dD} / \mathrm{dt}$, where $\mathrm{D}$ is the average feret diameter of grains. Compared with the interrupted samples of steel 1, it is clear that the interrupted transformed samples of steel 2 with 0.009 wt pct $\mathrm{Nb}$ always had fewer ferrite grains and a smaller average ferrite grain size than samples from steel 1 after 10,60 , and 120 seconds holding at $1023 \mathrm{~K}\left(750^{\circ} \mathrm{C}\right)$. However, the nucleation rate and the grain growth rate of steel 3 with 0.028 wt pct Nb were even lower than those of steel 2. When the ferrite grain size of steel 3 achieved a similar level to the final ferrite grain size after 180 seconds, the transformation was still in progress, and more ferrite grains would be formed to increase the total ferrite fraction, but the average ferrite grain size remained constant. These measured data were consistent with the kinetics plot in Figure 2(a). For isothermal transformations at other temperatures between $923 \mathrm{~K}\left(650^{\circ} \mathrm{C}\right)$ and $1023 \mathrm{~K}\left(750^{\circ} \mathrm{C}\right)$, the nucleation rate and the grain growth rate in steel 3 were always slower than those in steels 1 and 2, and therefore the transformation kinetics for steel 3 is always slower than steels 1 and 2 as shown in Figures 2(b) through (e). Since the only difference among the steels is 
the $\mathrm{Nb}$ content, and $\mathrm{Nb}$ atoms were all in solid solution at the beginning of the isothermal transformations, it can be concluded that solute $\mathrm{Nb}$ atoms have a retardation effect on both the ferrite nucleation rate and the ferrite grain growth rate.

In order to study the mechanism of the retardation effect caused by solute $\mathrm{Nb}$ atoms, the interrupted isothermally transformed samples of steel 3 were characterized using TEM. Figure 6(a) and (b) are the TEM images for carbon extraction replica samples of steel 3 after 60-second or 180-second isothermal transformation at $1023 \mathrm{~K}$ $\left(750^{\circ} \mathrm{C}\right)$. After 60 seconds, few $\mathrm{Nb}(\mathrm{C}, \mathrm{N})$ particles were found. However, many $\mathrm{Nb}(\mathrm{C}, \mathrm{N})$ particles with a particle size of $\sim 10 \mathrm{~nm}$ were seen to be segregated on grain boundaries after 180 -second holding at $1023 \mathrm{~K}\left(750^{\circ} \mathrm{C}\right)$. Since solute $\mathrm{Nb}$ atoms have a lower diffusion coefficient than carbon atoms in both austenite and ferrite [1], they cannot diffuse to a long distance within 180 seconds at $1023 \mathrm{~K}\left(750^{\circ} \mathrm{C}\right)$. Therefore, these TEM images indicate that solute $\mathrm{Nb}$ atoms segregate at the transformation interfaces during the isothermal transformation. The solute $\mathrm{Nb}$ atoms move with the transformation interface, and thus the interface mobility is reduced. This phenomenon is consistent with the solute drag theory [21-23]. In the carbon extraction replica technique, the matrix has been etched, with only precipitates left on the carbon film, and therefore the density of the precipitates is possibly more than its real value. In order to do a more accurate characterization, a small area across a ferrite/martensite grain boundary was lifted out using FIB, and the microstructure was analyzed using TEM under bright mode or high angle annular dark field (HAADF) mode, as shown in Figures 6(c) and (d). No obvious $\mathrm{Nb}(\mathrm{C}, \mathrm{N})$ particles can be seen in the sample with 60 second holding, but many small Nb precipitates can be seen in the sample with 180-second holding. From Figure 5(a), the ferrite grain growth rate in steel 3 is much slower than those of steels 1 and 2 up to 180-seconds isothermal transformation at $1023 \mathrm{~K}\left(750^{\circ} \mathrm{C}\right)$. Figure 2(a) shows that steels 1 and 2 have much more fraction transformed than steel 3 after 180-second isothermal transformation at $1023 \mathrm{~K}\left(750^{\circ} \mathrm{C}\right)$, which can be attributed to the influence of solute $\mathrm{Nb}$ atoms. 


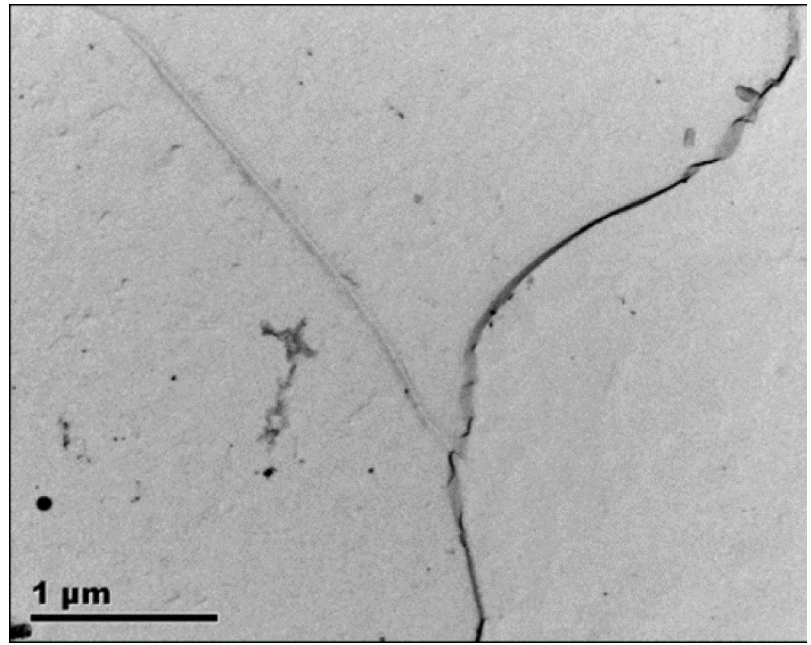

(a)

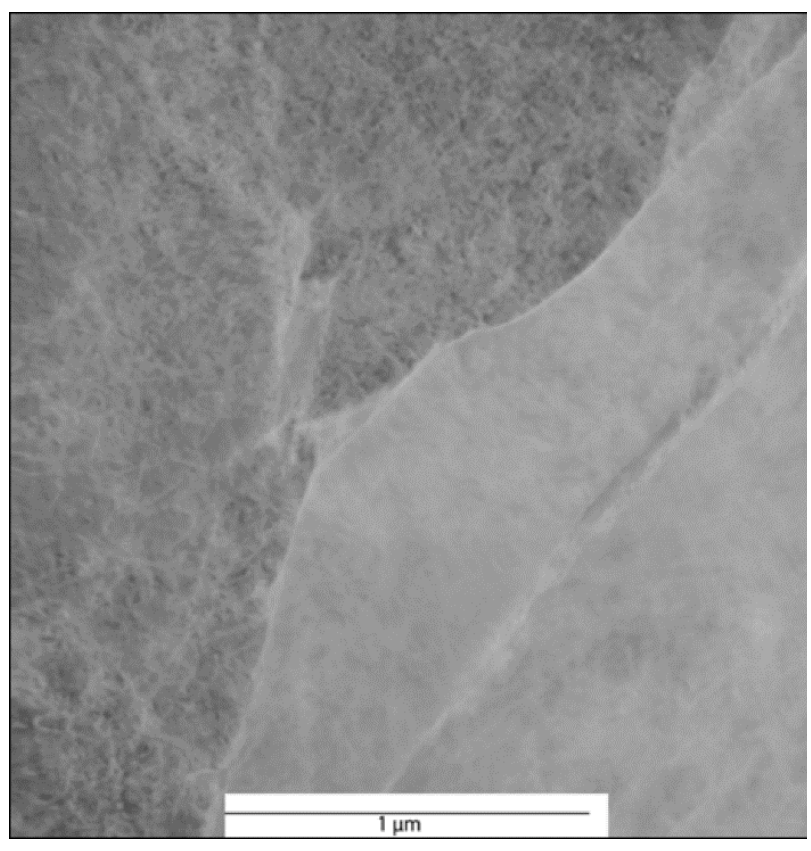

(c)

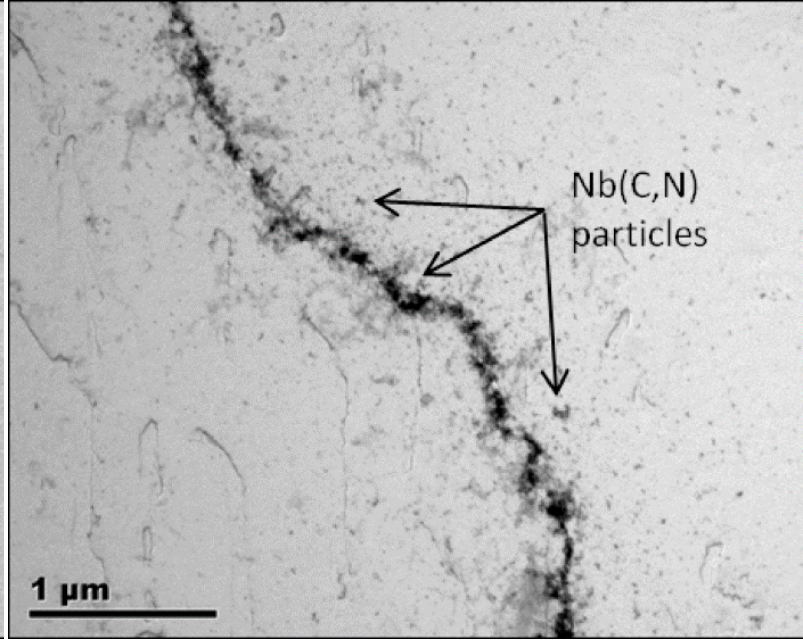

(b)

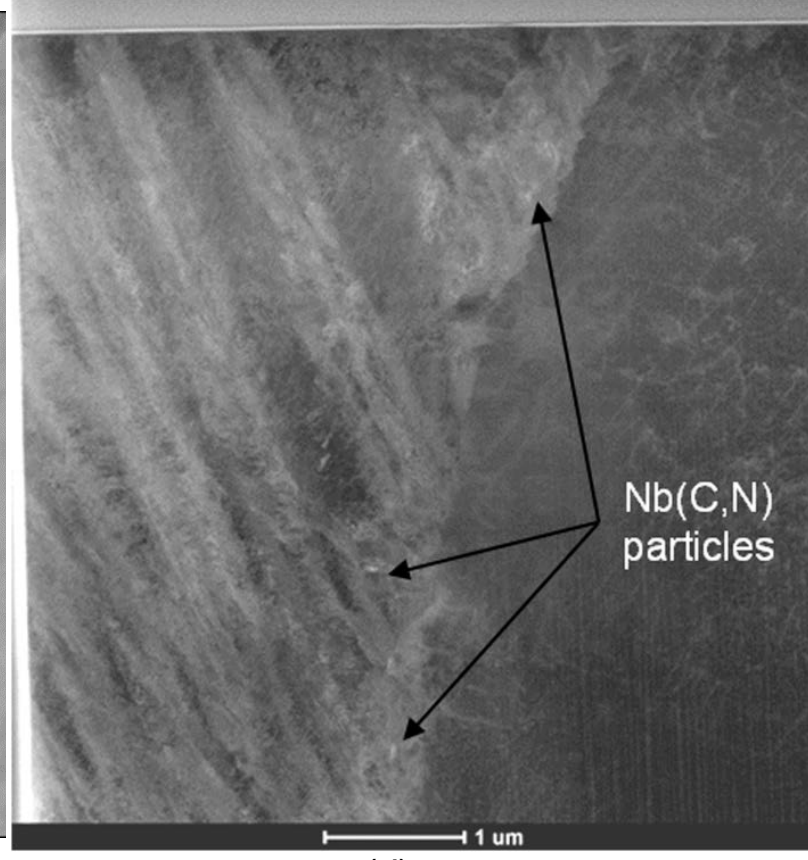

(d)

Fig. 6: TEM images for carbon extraction replica samples of steel 3 with (a) 60 seconds or (b) 180 seconds, interrupted isothermal transformations at $1023 \mathrm{~K}\left(750^{\circ} \mathrm{C}\right)$, and TEM images for FIB lift out samples of steel 3 with (c) 60 seconds or (d) 180 seconds, interrupted isothermal transformations at $1023 \mathrm{~K}\left(750^{\circ} \mathrm{C}\right)$.

\section{Effects of $\mathrm{Nb}$ precipitates on isothermal transformation}

In order to study the effects of $\mathrm{Nb}(\mathrm{C}, \mathrm{N})$ precipitates on the transformation behavior, samples were cooled to $1173 \mathrm{~K}\left(900^{\circ} \mathrm{C}\right)$ after austenitization at $1523 \mathrm{~K}\left(1250^{\circ} \mathrm{C}\right)$, and held for a certain time to allow solute $\mathrm{Nb}$ atoms to precipitate as $\mathrm{Nb}(\mathrm{C}, \mathrm{N})$ particles before the subsequent isothermal transformations. The isothermal transformation kinetics at $1023 \mathrm{~K}\left(750^{\circ} \mathrm{C}\right)$ of the four steels with 300-, 1200-, or 3600 -second holding at $1173 \mathrm{~K}\left(900^{\circ} \mathrm{C}\right)$ or without holding at $1173 \mathrm{~K}\left(900^{\circ} \mathrm{C}\right)$ are 
plotted in Figures 7(a) through (d), respectively. From Figure 7(a), there was a little difference in the transformation kinetics of the samples from steel 1, because steel 1 is $\mathrm{Nb}$-free, and 1200 -seconds holding at $1173 \mathrm{~K}\left(900^{\circ} \mathrm{C}\right)$ resulted in little prior austenite grain growth. From Figure 7(b), 1200-second holding at $1173 \mathrm{~K}\left(900^{\circ} \mathrm{C}\right)$ slightly accelerated the isothermal transformation kinetics of steel 2 , because solute $\mathrm{Nb}$ atoms which can delay the transformation kinetics had been precipitated as $\mathrm{Nb}(\mathrm{C}, \mathrm{N})$ particles during the holding at $1173 \mathrm{~K}\left(900^{\circ} \mathrm{C}\right)$. From Figure $7(\mathrm{c})$, it can be seen that the transformation kinetics became faster with increasing holding time at $1173 \mathrm{~K}\left(900^{\circ} \mathrm{C}\right)$ for steel 3 . However, there was a little increase in transformation kinetics between the sample with 1200-second holding and the sample with 3600 seconds, possibly because most solute $\mathrm{Nb}$ atoms had already been precipitated during 1200-second holding [2]. For steel 4 with 0.045 wt pct $\mathrm{Nb}$, holding at $1173 \mathrm{~K}$ $\left(900^{\circ} \mathrm{C}\right)$ for 3600 seconds significantly accelerated the isothermal transformation kinetics at $1023 \mathrm{~K}\left(750^{\circ} \mathrm{C}\right)$, as shown in Figure $7(\mathrm{~d})$.

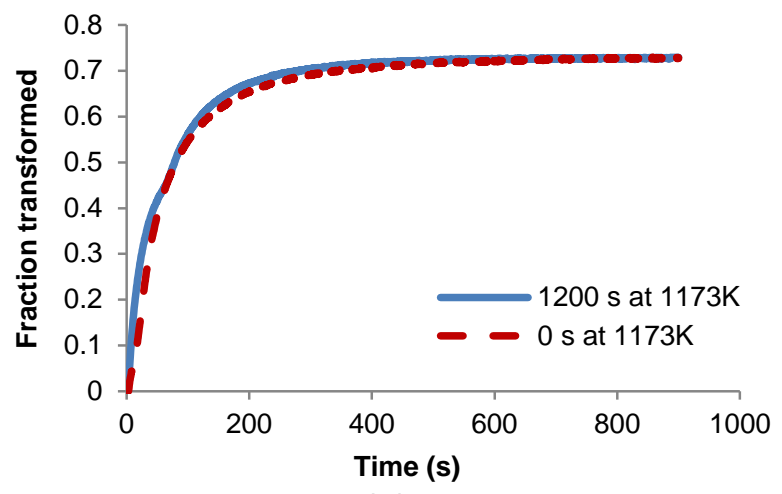

(a)

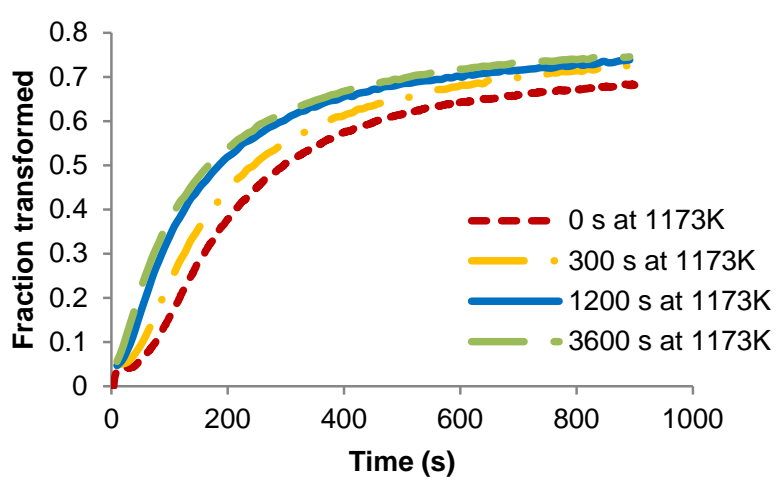

(c)

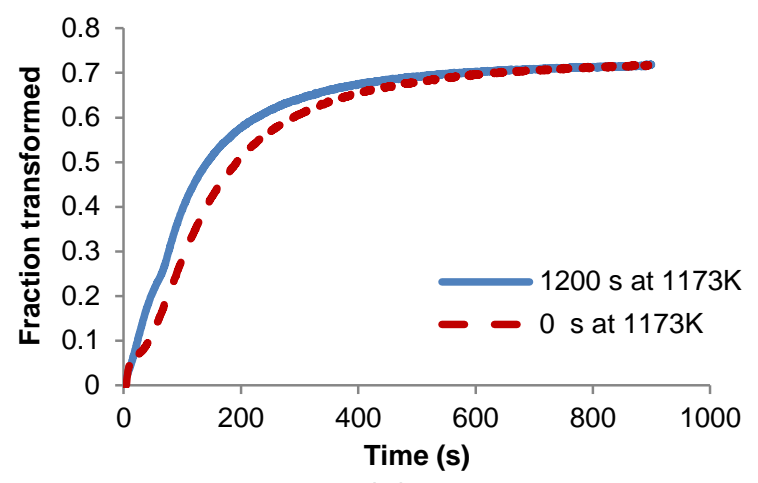

(b)

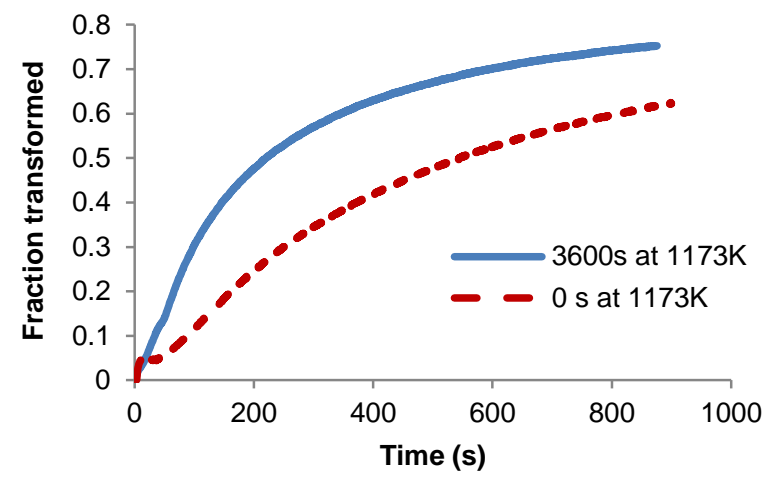

(d)

Fig. 7: Isothermal transformation kinetics at $1023 \mathrm{~K}\left(750^{\circ} \mathrm{C}\right)$ with or without holding at $1173 \mathrm{~K}$ $\left(900^{\circ} \mathrm{C}\right)$ for (a) steel 1, (b) steel 2, (c) steel 3, and (d) steel 4.

The presence of $\mathrm{Nb}(\mathrm{C}, \mathrm{N})$ particles in the sample from steel 4 with 1-hour holding at $1173 \mathrm{~K}\left(900^{\circ} \mathrm{C}\right)$ and then isothermal transformation at $1023 \mathrm{~K}\left(750^{\circ} \mathrm{C}\right)$ was studied 
using TEM, as shown in Figure 8. From a FIB lift out area across a ferrite/martensite interface, many $\mathrm{Nb}(\mathrm{C}, \mathrm{N})$ particles were observed, with a high density of dislocations around them. Some $\mathrm{Nb}(\mathrm{C}, \mathrm{N})$ particles were found near the interface, but there were also many particles away from the interface.

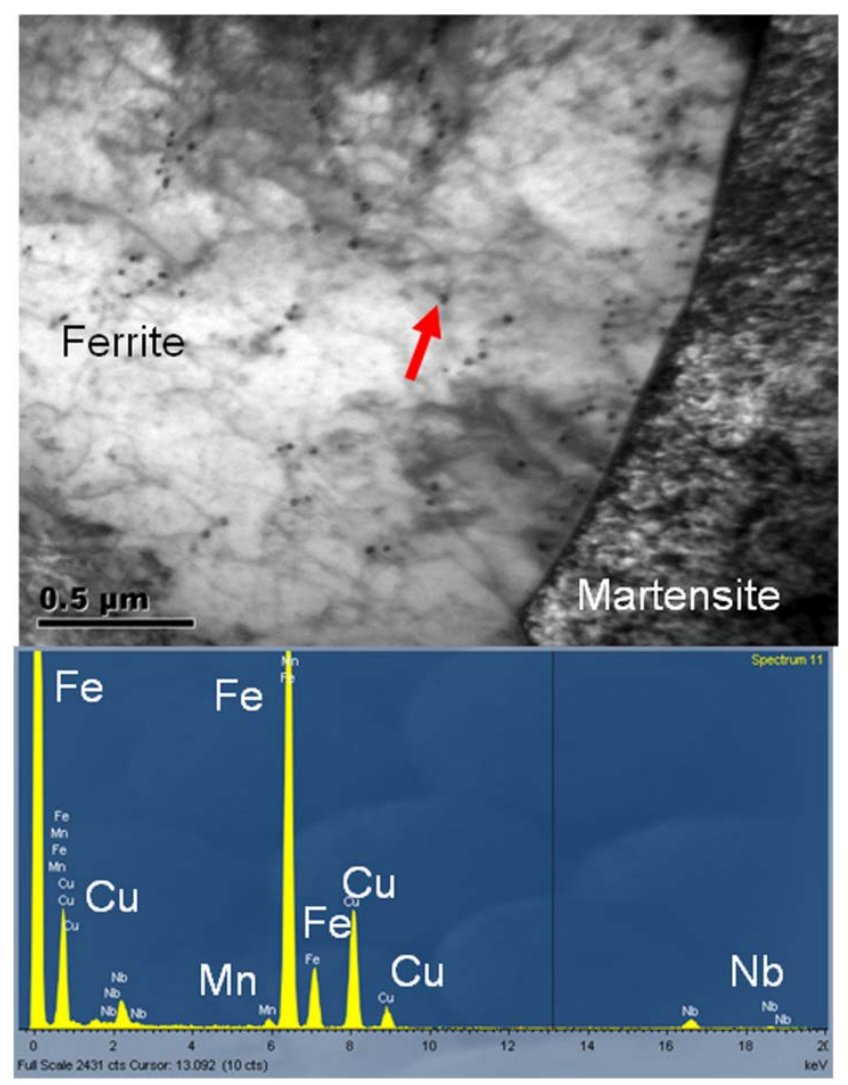

Fig. 8: A TEM image and the related EDX spectrum of a FIB lift out sample of steel 4 with 5 minutes austenitization at $1523 \mathrm{~K}\left(1250^{\circ} \mathrm{C}\right)$ and 1 hour holding at $1173 \mathrm{~K}\left(900^{\circ} \mathrm{C}\right)$ and then isothermal transformation at $1023 \mathrm{~K}\left(750^{\circ} \mathrm{C}\right)$.

It can be concluded that holding at $1173 \mathrm{~K}\left(900^{\circ} \mathrm{C}\right)$ accelerates the subsequent isothermal transformation kinetics. Solute $\mathrm{Nb}$ atoms precipitate as $\mathrm{Nb}(\mathrm{C}, \mathrm{N})$ particles, and thus the solute drag effect is reduced. $\mathrm{Nb}(\mathrm{C}, \mathrm{N})$ particles can exert a particle pinning effect on the transformation kinetics, but their effect appears to be much weaker than the solute drag effect according to the dilatometry results.

Figure 9 shows the dilatometer curves of isothermal transformation at $1023 \mathrm{~K}\left(750^{\circ} \mathrm{C}\right)$ for steels 3 and 5 after the austenitization at a temperature lower than the typical $\mathrm{Nb}(\mathrm{C}, \mathrm{N})$ dissolution temperatures in order to remain some pre-existing $\mathrm{Nb}(\mathrm{C}, \mathrm{N})$ particles and analyze their effect on transformation kinetics. Steels 3 and 5 with 5minutes austenitization at $1373 \mathrm{~K}\left(1100^{\circ} \mathrm{C}\right)$ both resulted in an average prior 
austenite grain size of $\sim 30 \mathrm{Im}$. It can be seen that although steel 5 has much more $\mathrm{Nb}$ content than steel 3 , its transformation kinetics is only slightly slower than steel 3.

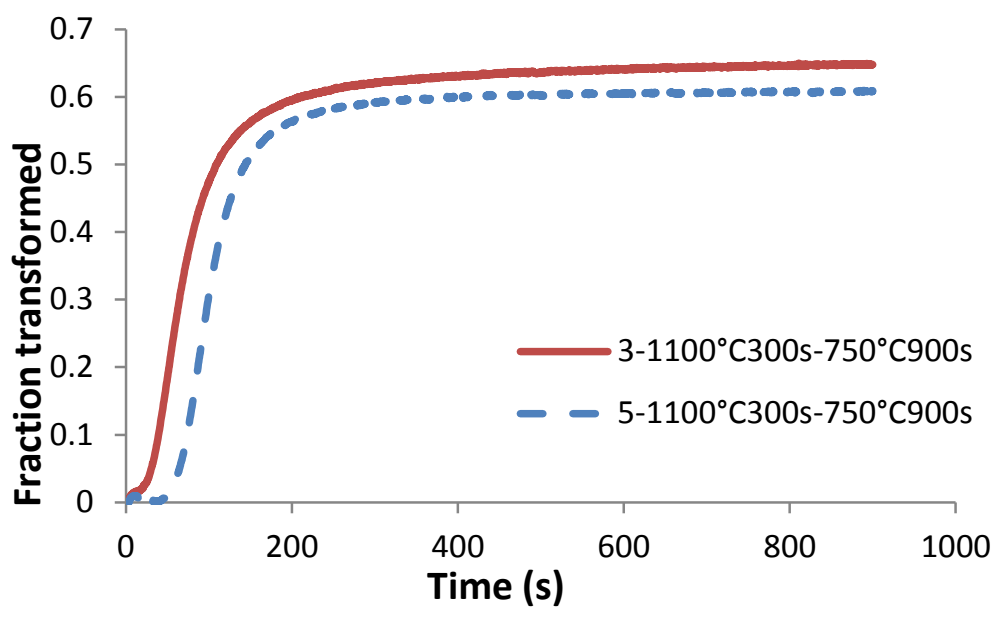

Fig. 9: Isothermal transformation kinetics at $750^{\circ} \mathrm{C}$ for steels 3 and 5 with austenitization temperatures below $\mathrm{Nb}(\mathrm{C}, \mathrm{N})$ dissolution temperature.

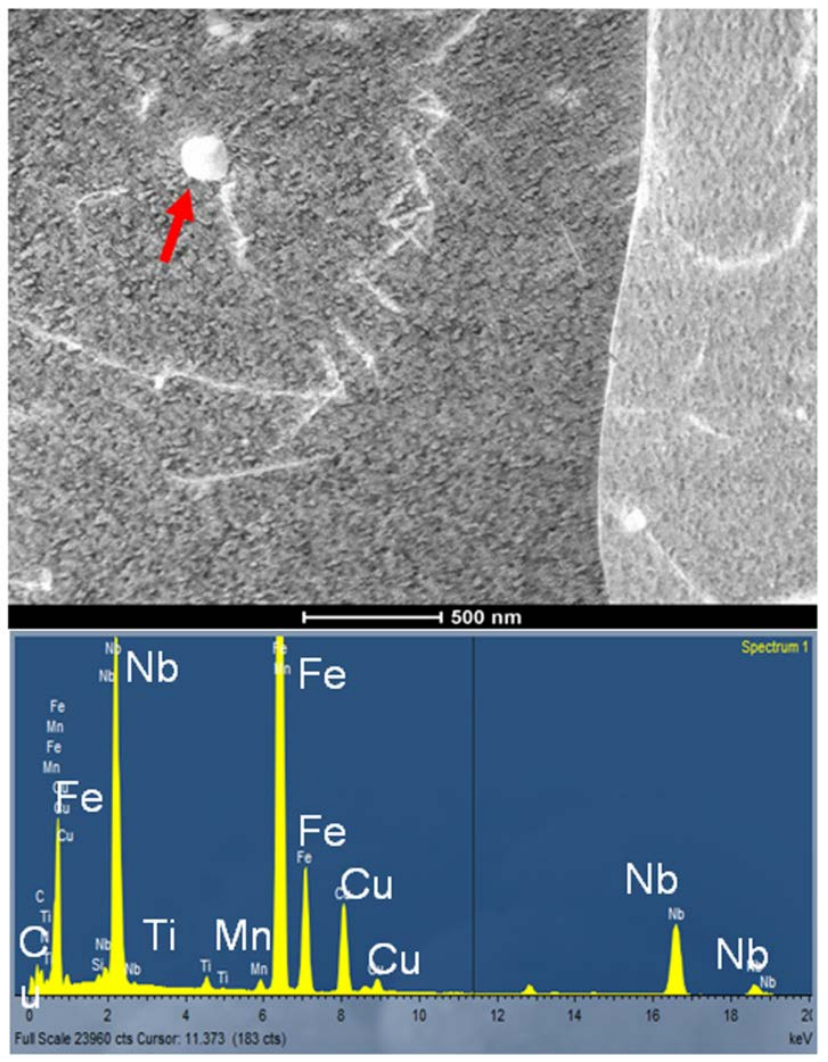

Fig. 10: A TEM image and the related EDX spectrum of a FIB lift out sample of steel 5 with 5 minutes austenitization at $1373 \mathrm{~K}\left(1100^{\circ} \mathrm{C}\right)$ and then isothermal transformation at $1023 \mathrm{~K}$ $\left(750^{\circ} \mathrm{C}\right)$.

Figure 10 shows an example of the effect of a pre-existing $\mathrm{Nb}(\mathrm{C}, \mathrm{N})$ particle on the isothermal transformation at $1023 \mathrm{~K}\left(750^{\circ} \mathrm{C}\right)$. The sample was from steel 5 which 
had undertaken an austenitization heat treatment at $1373 \mathrm{~K}\left(1100^{\circ} \mathrm{C}\right)$. After $15-$ minute isothermal transformation at $1023 \mathrm{~K}\left(750^{\circ} \mathrm{C}\right)$, a pre-existing $\mathrm{Nb}(\mathrm{C}, \mathrm{N})$ particle with the size about $100 \mathrm{~nm}$, which is much larger size than typical $\mathrm{Nb}(\mathrm{C}, \mathrm{N})$ particles precipitated during the isothermal transformation at $1023 \mathrm{~K}\left(750^{\circ} \mathrm{C}\right)$, can be found away from the grain boundary, and no high density of dislocations can be observed around the pre-existing particle. Therefore, It is reasonable to consider that the preexisting $\mathrm{Nb}(\mathrm{C}, \mathrm{N})$ particle makes much less contribution to delay transformation kinetics.

\section{Discussion}

All of the dilatometer results and microscopy images indicate that solute $\mathrm{Nb}$ has a retardation effect on transformation kinetics. For the samples directly quenched from $1523 \mathrm{~K}\left(1250^{\circ} \mathrm{C}\right)$ to the isothermal transformation temperatures, it is reasonable to assume all $\mathrm{Nb}$ atoms are in solid solution at the beginning of the isothermal transformation, because no $\mathrm{Nb}(\mathrm{C}, \mathrm{N})$ particles have been found using TEM in samples directly quenched from $1523 \mathrm{~K}\left(1250^{\circ} \mathrm{C}\right)$ to room temperature. During the isothermal transformations, a steel with a high $\mathrm{Nb}$ content was always found to have a slower transformation rate than a steel with a low $\mathrm{Nb}$ content, and the delay on transformation kinetics typically happened in the first few minutes. At the beginning, the transformation was delayed by solute $\mathrm{Nb}$ atoms, because all the $\mathrm{Nb}$ atoms were still in solid solution. $\mathrm{Nb}$ atoms have a low solubility in the ferrite lattice, and they prefer to segregate at prior austenite grain boundaries, where a large amount of defects are typically present. As a result, more energy is required for ferrite nucleation.

Even for the nucleated ferrite grains, many solute $\mathrm{Nb}$ atoms remain around the interface between the ferrite and austenite, because the newly formed ferrite grains are quite small, and the diffusion of solute $\mathrm{Nb}$ atoms in iron matrix is quite slow. $\mathrm{Nb}$ is a ferrite stabilizer, and thus the chemical potential of solute $\mathrm{Nb}$ atoms in ferrite is lower than that in austenite. In addition, there should be a potential well at the interface to explain the attraction of solute atoms. A schematic diagram of chemical potential across a ferrite/austenite interface is shown in Figure 11, where $\mu_{N b}^{\alpha}$ is the interaction energy between solute Nb atoms and ferrite, $\mu_{N b}^{\gamma}$ is the interaction energy 
between solute $\mathrm{Nb}$ atoms and austenite, $2 \Delta E$ is the difference of interaction energy for solute $\mathrm{Nb}$ atoms in austenite and ferrite phases, $\delta$ is the half width of the boundary between ferrite and austenite, and $E_{0}-\Delta E$ is the potential well showing the binding energy of $\mathrm{Nb}$ atoms at the boundary.

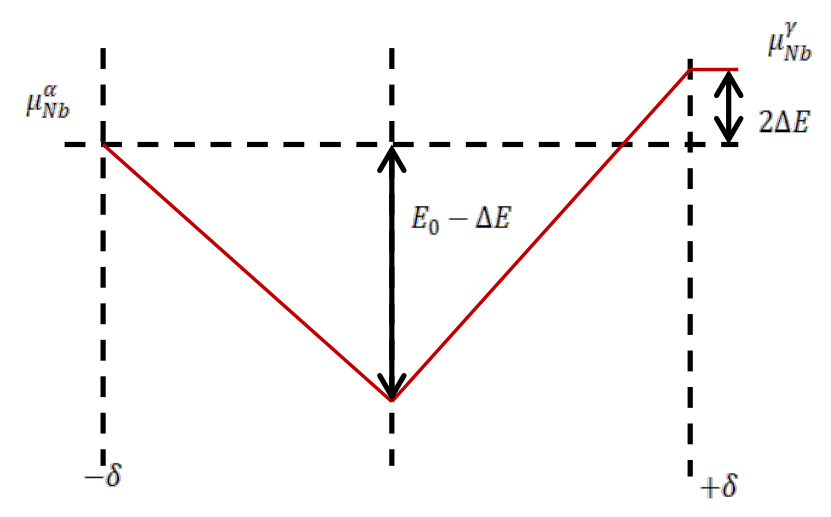

Fig. 11: Schematic diagrams of chemical potential profile across the interface between austenite $(\gamma)$ and ferrite $(\alpha)$.

A brief model can be developed to roughly estimate the diffusion rate of $\mathrm{Nb}$ atoms during the phase transformation. For a $\mathrm{NbC}$ particle precipitated at a prior austenite grain boundary, it can be assumed that the local $\mathrm{Nb}$ mole fraction is 0.5 . Although $\mathrm{Nb}$ contents in the steels are not high enough to fully fill the prior austenite grain boundaries, it can be assumed that the fastest diffusion case is when some boundaries are full of $\mathrm{NbC}$ precipitates and there are no $\mathrm{Nb}$ particles inside the grains. However, there are many grain boundaries and the diffusion from one grain boundary could be affected by the neighboring boundaries, and thus the multisources diffusion in a finite space system can be schematically as shown in Figure 12. $\mathrm{Nb}$ atoms diffuse from grain boundaries into grains, and the case can be simplified as a 1D model for the short distance diffusion, and the real 3D case can be considered as diffusion in different directions which will not have an order difference in diffusion rate. For a system with many sources, if the distance between each source is $2 \mathrm{l}$, the $\mathrm{Nb}$ concentration profile can be described as Eq. 1 [26]:

$$
C=\frac{1}{2} C_{0} \sum_{n=-\infty}^{\infty}\left[\operatorname{erf} \frac{h+2 n l-x}{2 \sqrt{D t}}+\operatorname{erf} \frac{h-2 n l+x}{2 \sqrt{D t}}\right]
$$

If only $\mathrm{n}=0,1,-1$ are considered, the $\mathrm{Nb}$ concentration can be described as: 


$$
\begin{gathered}
C=\frac{1}{2} C_{0}\left[\operatorname{erf} \frac{h-x}{2 \sqrt{D t}}+\operatorname{erf} \frac{h+x}{2 \sqrt{D t}}+\operatorname{erf} \frac{h+2 l-x}{2 \sqrt{D t}}+\operatorname{erf} \frac{h-2 l+x}{2 \sqrt{D t}}+\operatorname{erf} \frac{h-2 l-x}{2 \sqrt{D t}}\right. \\
\left.+\operatorname{erf} \frac{h+2 l+x}{2 \sqrt{D t}}\right]
\end{gathered}
$$

where $C_{0}=0.5$ is the initial $\mathrm{Nb}$ concentration at boundaries, $\mathrm{h}$ is the half width of a grain boundary, I is the half diameter of a grain, and D is the diffusion coefficient of $\mathrm{Nb}$ in austenite or ferrite. The diffusion coefficient can be calculated using the typical Arrhenius equation:

$$
D=D_{0} \exp \left(\frac{-Q}{R T}\right)
$$

The calculated $\mathrm{Nb}$ concentration profiles after various times at $1023 \mathrm{~K}\left(750^{\circ} \mathrm{C}\right)$ are shown in Figure 13. In the calculation, $\mathrm{h}$ is chosen as $5 \mathrm{~nm}$, and $\mathrm{I}$ is chosen as $40 \mu \mathrm{m}$. For $\mathrm{Nb}$ diffusion in austenite, $\mathrm{D}_{0}=8 \mathrm{e}-5 \mathrm{~m}^{2} / \mathrm{s}$, and $\mathrm{Q}=265 \mathrm{~kJ} / \mathrm{mol}$, for $\mathrm{Nb}$ diffusion in ferrite $\mathrm{D}_{0}=5 \mathrm{e}-3 \mathrm{~m}^{2} / \mathrm{s}$, and $\mathrm{Q}=250 \mathrm{~kJ} / \mathrm{mol}[1]$.

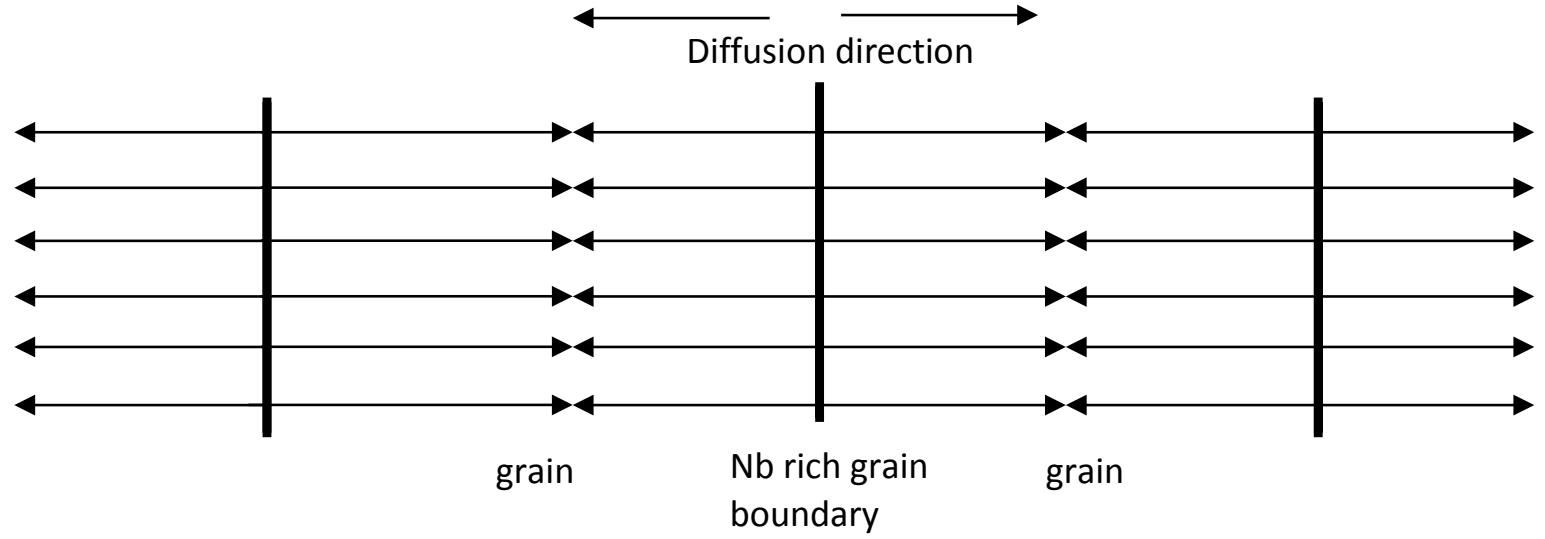

Fig. 12: Schematic diagram of $\mathrm{Nb}$ atoms diffusion in steels at a high temperature.

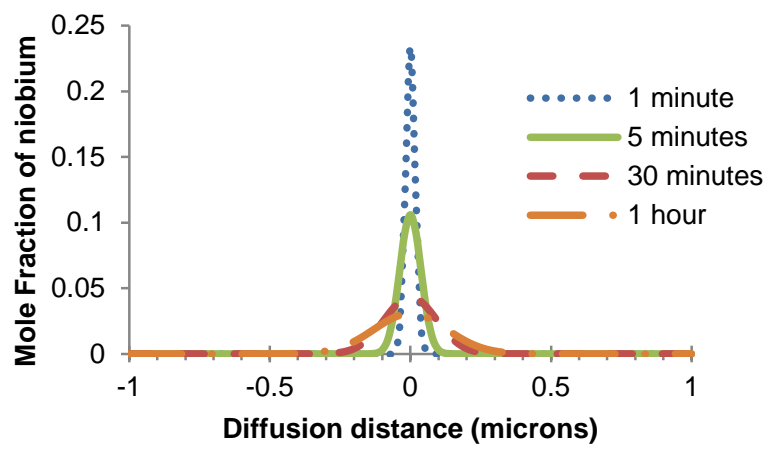

(a)

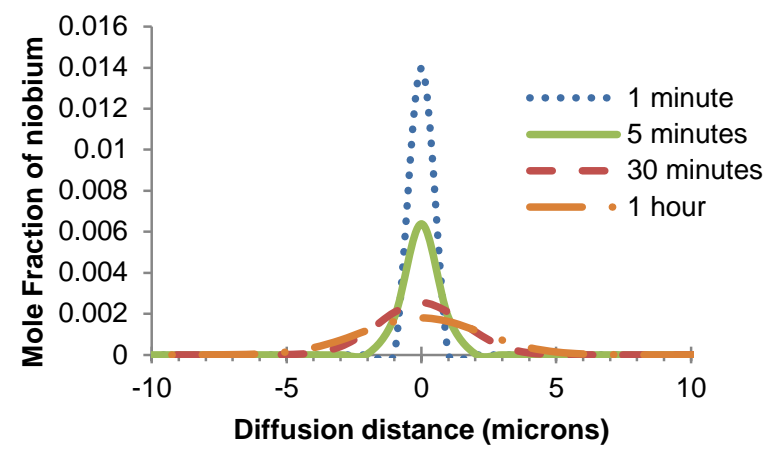

(b)

Fig. 13: $\mathrm{Nb}$ concentration profiles after various times diffusion at $1023 \mathrm{~K}\left(750^{\circ} \mathrm{C}\right)$ from grain boundaries into (a) austenite grains, and (b) ferrite grains, in the system shown in Figure 12. 
For the sample isothermally transformed at $1023 \mathrm{~K}\left(750^{\circ} \mathrm{C}\right)$, the prior austenite grain size was $80 \mathrm{~lm}$ and the final ferrite grain size was $\sim 20 \mu \mathrm{m}$. From the dilatometer results, it is reasonable to estimate that the ferrite/austenite interface moves at an average rate of a few microns per minute at the beginning of ferrite grain growth stage during the isothermal transformation at $1023 \mathrm{~K}\left(750^{\circ} \mathrm{C}\right)$. According to Figure 13 , the diffusion of solute $\mathrm{Nb}$ atoms at this temperature is much slower than this rate. As a result, it takes extra force to 'drag' these solute $\mathrm{Nb}$ atoms to move with the interface, and therefore the transformation rate is slowed down. However, from the experimental observations, $\mathrm{Nb}$ atoms will be precipitated as $\mathrm{Nb}(\mathrm{C}, \mathrm{N})$ particles after a few minutes holding at $1023 \mathrm{~K}\left(750^{\circ} \mathrm{C}\right)$, and then the solute drag effect will be significantly reduced and the phase transformation kinetics will be much faster which is consistent with the dilatometer results as in Figure 5. From the literature [27,28], some researchers attribute the retardation effect caused by solute $\mathrm{Nb}$ atoms to the increase in the activation energy of carbon diffusion, because the rate of the phase transformation from austenite to ferrite is typically controlled by carbon diffusion, and thus the ferrite grain growth rate is reduced by the presence of solute $\mathrm{Nb}$ atoms.

\section{Conclusions}

The effects of $\mathrm{Nb}$ on phase transformations from austenite to ferrite have been investigated. Dilatometry results indicate that solute $\mathrm{Nb}$ atoms have a retardation effect on transformation kinetics from austenite to ferrite. This effect was significant on isothermal transformations above $923 \mathrm{~K}\left(650^{\circ} \mathrm{C}\right)$. From microstructural analysis of interrupted isothermally transformed samples, the solute drag effect caused by many solute $\mathrm{Nb}$ atoms segregated at the austenite/ferrite interface has been investigated. Both ferrite nucleation rate and grain growth rate were retarded by the presence of solute $\mathrm{Nb}$ atoms. However, if solute $\mathrm{Nb}$ atoms are precipitated as $\mathrm{Nb}$ carbo-nitride particles before transformation, the particle pinning effect is much weaker than the solute drag effect. Solute $\mathrm{Nb}$ atoms also have an effect on the temperature range for reconstructive transformation, and thus the final microstructure is affected.

\section{Acknowledgement}

The authors gratefully thank Tata Steel UK Limited and Loughborough University for funding this work. 


\section{References}

[1] A. J. DeArdo: Proceedings of the International Symposium Niobium 2001, TMS, Orlando, 2001. P427.

[2] F. Fazeli, and M. Militzer: J. Iron Steel. Res. Int., 2011, vol. 18, no. 1, pp. 658663.

[3] N. Fujita, and H. K. D. H. Bhadeshia: Mater. Sci. Tech., 2001, vol. 17, no. 4, pp. 403-408.

[4] J. Kim, J. G. Jung, D. H. Kim, Y. K. Lee: Acta Mater., 2013, vol. 61, no.19, pp. 7437- 7443 .

[5] E. G. Dere, H. Sharma, S. E. Offerman, J. Sietsma: Solid State Phenomena, 2011. vols. 172-174, pp. 499-504.

[6] M. Gomez, S. F. Medina, A. Quispe, and P. Valles: ISIJ Int., 2002, vol. 42, no.4, pp. 423-431.

[7] C. Fossaert, G. I. Rees, T. Maurickx, and H. K. D. H. Bhadeshia: Metall. Mater. Trans. A, 1995, vol. 26, pp. 21-30.

[8] F. De Kazinczy, A. Axnas, and P. Pachleitner: Jernkont Ann, 1963, vol. 147, pp. 408-433.

[9] G. I. Rees, J. Perdrix, T. Maurickx, and H. K. D. H. Bhadeshia: Mater. Sci. Eng. A, 1995, vol. 194, pp. 179-186.

[10] S. C. Hong, S. H. Lim, K. J. Lee, D. H. Shin, and K. S. Lee: ISIJ Int., 2002, vol. 42, no. 12, pp. 1461-1467.

[11] J. Cao, Q. Liu, Q. Yong, and X. Sun: J. Iron. Steel. Res. Int., 2007, vol. 14, no. 3, pp. 51-55.

[12] M. Gomez, S. F. Medina, and P. Valles: ISIJ Int., 2005, vol. 45, no. 11, pp. 1711-1720.

[13] M. G. Akben, I. Weiss, and J. J. Jonas: Acta Metall., 1981, vol. 29, no. 1, pp. 111-121.

[14] S. H. Cho, K. B. Kang, and J. J. Jonas: ISIJ Int., 2001, vol. 41, no.1, pp. 6369.

[15] Y. C. Jung, H. Ueno, H. Ohtsubo, K. Nakai, and Y. Ohmori: ISIJ Int., 1995, vol. 35, no.8, pp. 1001-1005.

[16] M. Suehiro, Z. K. Liu, and J. Agren: Acta Mater., 1996, vol. 44, no.10, pp. 4241-4251. 
[17] M. Militzer, E. B. Hawbolt, and T. R. Meadowcroft: Metall. Mater. Trans. A, 2000, vol. 31, no.4, pp. 1247-1259.

[18] L. Wang, S. V. Parker, A. J. Rose, G. D. West, and R. C. Thomson: J. Iron Steel. Res. Int., 2011, vol. 18, no. 1, pp. 208-212.

[19] J. W. Cahn: Acta Metall., 1962, vol. 10, no.9, pp. 789-798.

[20] M. Hillert, and B. Sundman: Acta Metall., 1976, vol. 24, no. 8, pp. 731-743.

[21] G. R. Purdy, and Y. J. M. Brechet: Acta Metall. Mater., 1995, vol. 43, no.10, pp. 3763-3774.

[22] M. Enomoto: Acta Mater., 1999, vol. 47, no. 13, pp. 3533-3540.

[23] P. J. Felfer, C. R. Killmore, J. G. Williams, K. R. Carpenter, S. P. Ringer, and J. M. Cairney: Acta Mater., 2012, vol. 60. no.13, pp. 5049-5055.

[24] F. Fazeli, and M. Militzer:Metall. Mater. Trans. A, 2005, vol. 36, no.6, pp. 1395-1405.

[25] T. Furuhara, T. Yamaguchi, G. Miyamoto, and T. Maki: Mater. Sci. Tech., 2010, vol. 26, no.4, pp. 392-397.

[26] J. Crank: The Mathematics of Diffusion, Clarendon Press, Oxford, 1975, p. 11.

[27] K. J. Lee, and J. K. Lee: Scripta Mater., 1999, vol. 40, no. 7, pp. 831-836.

[28] M. H. Thomas and G. M. Michal: Proceeding of International Conference on Solid - Solid Phase Transformations, p. 469, TMS of AIME, Pittsburgh, 1981. 